\title{
The effect of physicochemical properties of fuels on ecological parameters of a diesel engine
}

\begin{abstract}
The objective of the research results of which are presented in this paper was to determine the effect of selected physicochemical properties of fuels on ecological parameters of a diesl engine. Physicochemical parameters of fuel have a decisive effect on correct functioning, operating parameters, and cleanliness of the exhaust gas emitted to the environment by any combustion engine. Results of physicochemical studies can be useful in developing fuels blends of specific properties, whereas results obtained in the course of tests carried out on an engine test bench allow to optimize parameters of the fuel injection process with the aim to reduce emissions of toxic compounds to atmosphere.
\end{abstract}

Key words: fuel properties, diesel engine, ecological parameters

\section{Introduction}

Until quite recently, toxicity of fuels were considered only from the point of view of hazards to human health and life. Nowadays, the problem is considered from the perspective of protection of the whole nature. Information about toxic properties of any specific fuel must be disclosed in the Material Safety Data Sheet according to EU Directive 91/155/EEC [4, 7].

Adverse effects of fuels used in transport on natural environment can be both direct and indirect. As far as the direct environmental effect are concerned, the effects can be categorized as follows [1,3]:

- pollution of ecosystems,

- toxic effects on living organisms,

- persistence in the environment.

Indirect effects on the natural environment are related mainly to toxic product of combustion of engine fuels which, according to applicable normative instruments, include: carbon oxide $(\mathrm{CO})$, nitrogen oxides $\left(\mathrm{NO}_{\mathrm{x}}\right)$, hydrocarbons (HC), and particulate matter (PM). Apart from that, exhaust gases contain many toxic compounds which are not subject to any limits. For instance, 65 chemical compounds have been identified in diesel fuel, including 14 mutagenic polycyclic aromatic compounds of which 9 are considered carcinogenic $[1,6,10]$.

Fuels containing fractions with high boiling point are characterized with increased emission of particulate matter, more exhaust smoke, and lower content of nitrogen oxides. The effect of presence of heavy fractions in the fuel on emissions is of indirect nature, via an increased tendency to develop the carbon deposit on injector nozzles and in combustion chamber. This in turn disrupts the course of the combustion process and leads to decrease of its effectiveness, increase of emissions of unburned hydrocarbons, carbon oxide, and particulate matter. To prevent this, fuels are treated with suitable washing detergents.

Another factors affecting toxicity of exhaust gases are fuel viscosity and density, as these parameters have a direct effect on the volume of the fuel charge delivered to the combustion chamber and the quality of spraying which are decisive for the course of combustion process. On the other hand, higher fuel density results in increased emissions of particulate matter, especially in transient operating conditions of combustion engines [1, 2, 5, 8, 9, 12].

A particularly harmful component of fuels is sulfur presence of which is the cause of emission of sulfur oxides, particulate matter, and nitrogen oxides to atmosphere. In the course of combustion process occurring in engine, sulfur contained in fuel is oxidized to $\mathrm{SO}_{2}$ which, oxidized subsequently to $\mathrm{SO}_{3}$, can react with water produced in the same combustion process and create sulfuric acid. Sulfur dioxide and trioxide, emitted together with the exhaust gas to the atmosphere, are the cause of the so-called acid rains. Moreover, sulfur acid is the cause of corrosion attacking engine components $[1,11]$.

Fuels containing aromatic hydrocarbons in their formulations show also an adverse effect on cleanliness of engine exhaust gases. Increased quantity of these hydrocarbons in fuel contributes to increased emissions of nitrogen compounds and particulate matter [11].

\section{Experimental setup and methodology}

The measuring devices used to determine basic parameters of fuels selected for testing (Figs 1-3) included instruments constituting research equipment of the Consumable Materials Laboratory run by the Department of Combustion Engines and Transport, Rzeszow University of Technology [5]. The present paper presents result obtained for commercially available diesel fuel $(\mathrm{ONH})$, FAME (Fatty Acid Methyl Esters) (B100), and a blend containing $40 \%$ of rape oil and $60 \%$ of commercially available diesel fuel (OR40). Much wider range of fuel blends configurations was presented in [7] where it has been found that the OR40 blend is characterized with the highest usefulness among the other tested fuels. Therefore this paper presents results obtained for this configuration. 
a)

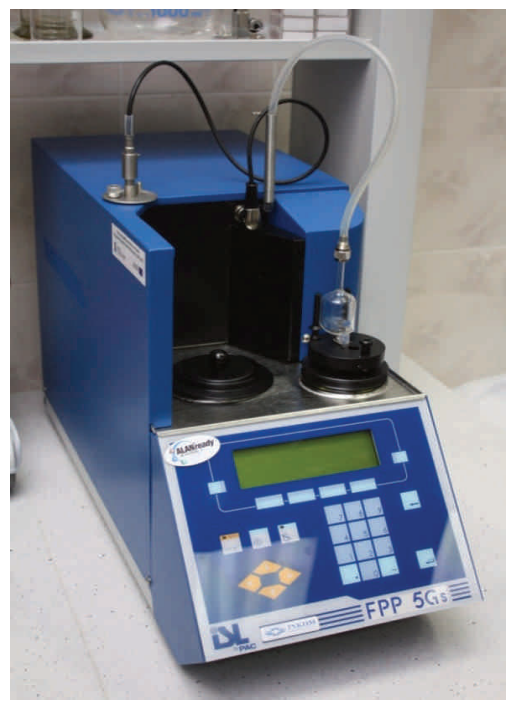

b)

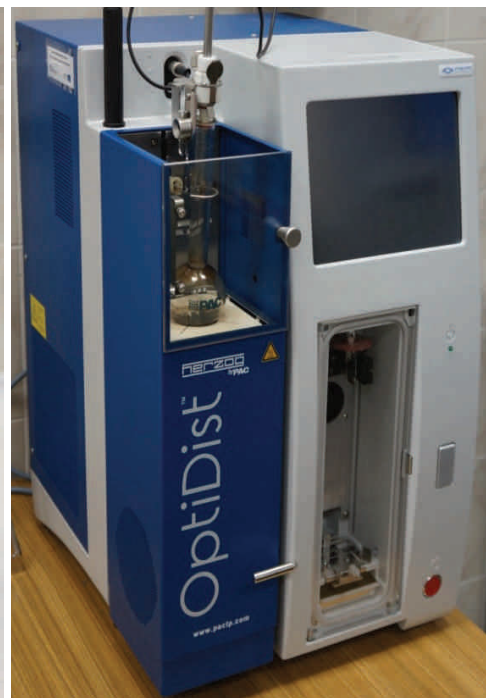

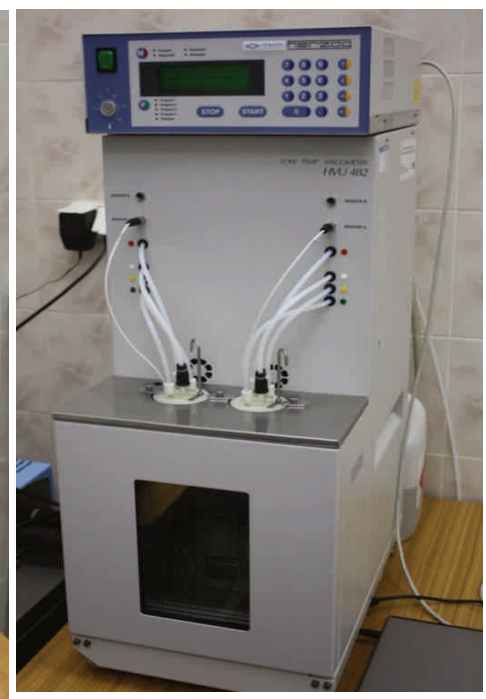

Fig. 1. Research devices: (a) FPP 5Gs Automated Cold Filter Plugging Point Analyzer; (b) OptiDist Automated Distillation Analyzer for Refining; (c) HVU 482 Automated Ubbelohde Viscometer

a)

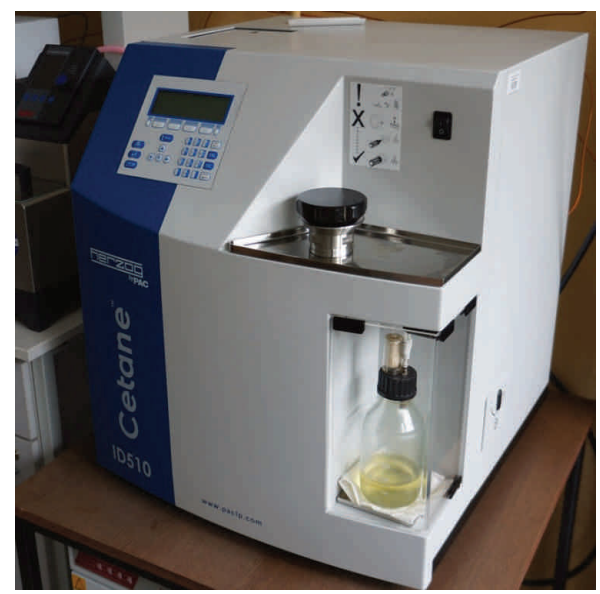

b)

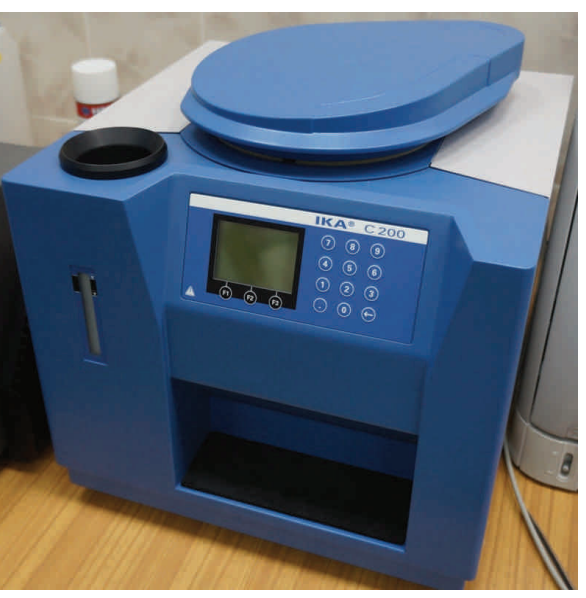

Fig. 2. Research devices: (a) Cetane ID 510 Cetane Analyzer; (b) IKA C200 Automated Bomb Calorimeter

b)

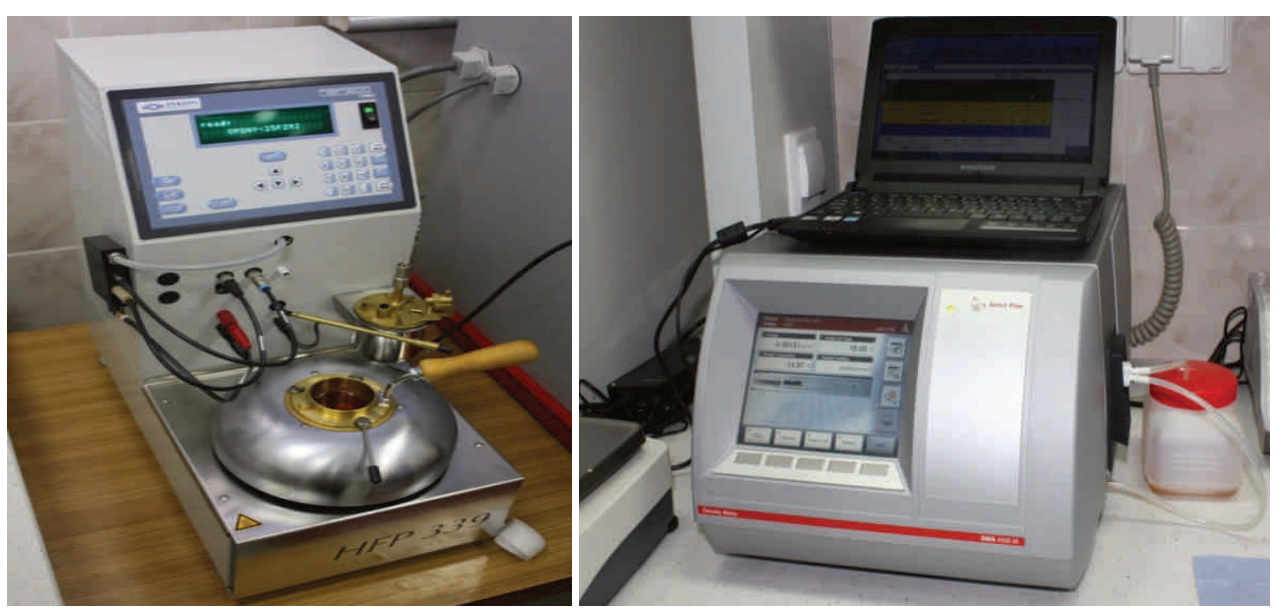

Fig. 3. Research devices: (a) HFP 339 Pensky-Martens Flash Point Analyzer; (b) DMA 4500 M Accurate Density Meter 
Parameters of the tested fuels as far as the required measurements are concerned, were determined according to procedures defined in applicable standards.

To study the effect of fuel on ecological-related parameters, a single-cylinder diesel test engine of SB3.1/CR type was used equipped with a fuel injection system of Common Rail type allowing to inject five fuel charges per engine working cycle at different injection pressures, developed in the Department of Combustion Engines and Transport, Rzeszow University of Technology. The engine is a modified version of the experimental engine SB3.1 designed and constructed by the Communication Equipment Research and Development Center in Mielec (Fig. 4). Technical details of SB3.1 engine are presented in Table 1.

Table 1. Technical specification of SB3.1 with original fuel system [9]

\begin{tabular}{|l|c|}
\hline \multicolumn{1}{|c|}{ Parameter type } & Parameter value \\
\hline Number of cylinder & 1 \\
\hline Number of strokes & 4 \\
\hline Cooling system & liquid \\
\hline Piston stroke & $146 \mathrm{~mm}$ \\
\hline Cylinder diameter & $127 \mathrm{~mm}$ \\
\hline Displacement volume & $1850 \mathrm{~cm}^{3}$ \\
\hline Compression ratio & 15.75 \\
\hline Engine rated power & $23 \mathrm{~kW}$ \\
\hline Rated speed & $2200 \mathrm{rpm}$ \\
\hline Maximum torque & $110 \mathrm{Nm}$ \\
\hline Speed at maximum torque & $1600 \mathrm{rpm}$ \\
\hline $\begin{array}{l}\text { Engine rotation sense (as seen } \\
\text { from flywheel side) }\end{array}$ & $\mathrm{CCW}$ \\
\hline Oil lubrication system & circulating forced \\
\hline Valve clearance on cold engine & $0.5 \mathrm{~mm}$ \\
\hline Injector opening static pressure & $16.67+0.49 \mathrm{MPa}$ \\
\hline
\end{tabular}

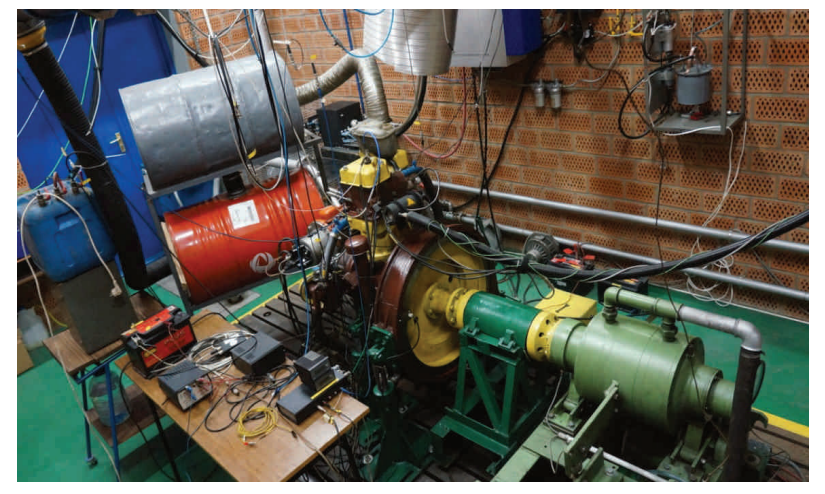

Fig. 4. SB-3.1 single-cylinder experimental engine equipped with CR-type fuel system

After completion of preliminary engine tests aimed at determination of measuring points, the actual tests were carried out for engine performance characteristics the course of which is one of the most important features used in comparative and functional analyses concerning combustion engines. The criterion adopted for the maximum load applied to the test engine, at constant injection pressure $(100 \mathrm{MPa})$ and injection advance angle $\left(18^{\circ} \mathrm{CA}\right)$, was the smoke opacity value of $25 \mathrm{HRT}$. Individual measuring points were selected for rotational speeds in the range
1200-1600 rpm with step of $100 \mathrm{rpm}$. The selected parameter was the injection duration (injector controlling pulse duration time). The determined measuring points are listed in Table 2.

Table 2. The engine control parameters determined in the course of research

\begin{tabular}{|l|c|c|}
\hline No. & $\begin{array}{c}\text { Engine speed } \\
\mathrm{n}[\mathrm{rpm}]\end{array}$ & Injection duration $\mathrm{t}_{\mathrm{is}}[\mu \mathrm{s}]$ \\
\hline 1. & 1200 & 3150 \\
\hline 2. & 1300 & 3000 \\
\hline 3. & 1400 & 2750 \\
\hline 4. & 1500 & 2600 \\
\hline 5. & 1600 & 2600 \\
\hline
\end{tabular}

The soot content in exhaust gases was measured with the use of AVL Micro Soot Sensor measuring system (Fig. 5). Fig. 6 is a screenshot of the program window used to record the soot content in exhaust gases.

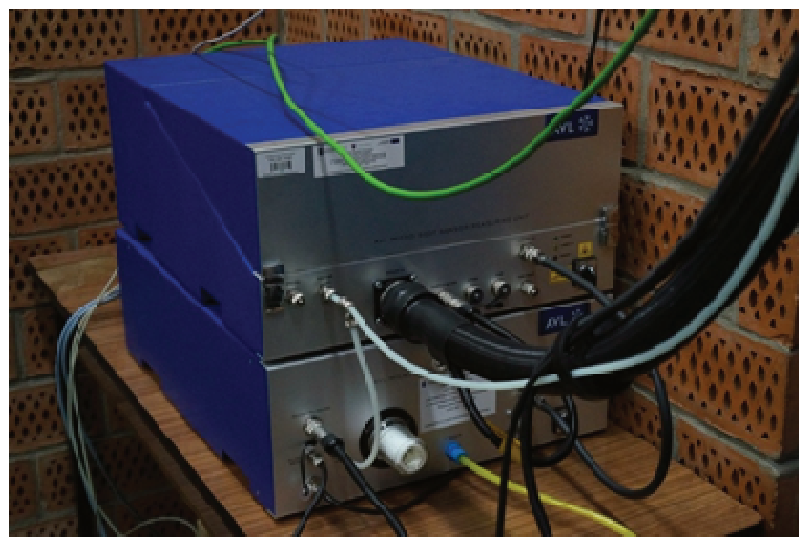

Fig. 5. AVL Micro Soot Sensor system for measuring soot concentrations in the exhaust gases

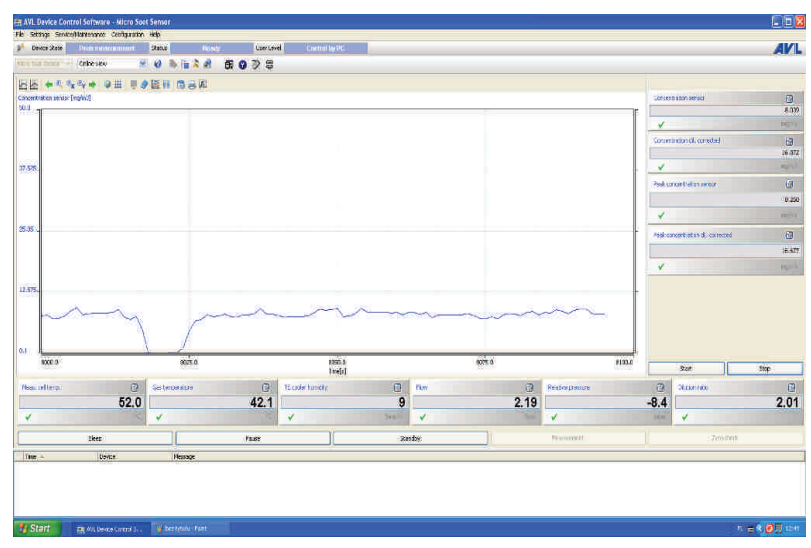

Fig. 6. A view of program window used to record soot concentration in exhaust gases [7]

\section{Results and discussion}

As a result of the performed research, values of the following physicochemical properties characterizing the fuels selected for the assessment were measured: density at $15^{\circ} \mathrm{C}$; flash point; cold filter plugging point (CFPP); kinematic viscosity at $40^{\circ} \mathrm{C}$; derived cetane number (DCN); and fraction composition. The obtained results are presented in Table 3. 
Table 3. Parameters of the tested fuels

\begin{tabular}{|c|c|c|c|c|c|}
\hline \multicolumn{2}{|c|}{ Fuel parameters } & Unit & $\mathrm{ONH}$ & B100 & OR40 \\
\hline \multicolumn{2}{|c|}{ Density at $15^{\circ} \mathrm{C}$} & $\mathrm{g} / \mathrm{cm}^{3}$ & 0.83411 & 0.88343 & 0.86849 \\
\hline \multicolumn{2}{|c|}{ Flash point } & ${ }^{\circ} \mathrm{C}$ & 59 & 149.5 & 66.5 \\
\hline \multicolumn{2}{|l|}{ CFPP } & ${ }^{\circ} \mathrm{C}$ & -29 & -22 & -17 \\
\hline \multicolumn{2}{|c|}{$\begin{array}{l}\text { Kinematic viscosity } \\
\text { at } 40^{\circ} \mathrm{C}\end{array}$} & $\mathrm{mm}^{2} / \mathrm{s}$ & 2.9491 & 4.3288 & 7.8408 \\
\hline \multicolumn{2}{|c|}{$\begin{array}{l}\text { Higher heating } \\
\text { value }\end{array}$} & $\mathrm{MJ} / \mathrm{kg}$ & 43037 & 37417 & 40516 \\
\hline \multicolumn{2}{|l|}{$\mathrm{DCN}$} & - & 53.1 & 52.27 & 51.06 \\
\hline \multirow{3}{*}{$\begin{array}{l}\text { Fractional } \\
\text { composition }\end{array}$} & E250 & vol $\%$ & 40 & 0 & 24 \\
\hline & E350 & $\mathrm{vol} \%$ & 96 & 90 & 93 \\
\hline & T95 & ${ }^{\circ} \mathrm{C}$ & 345 & 354 & - \\
\hline
\end{tabular}

According to the adopted objective, engine tests allowed to determine the effect of physicochemical properties of selected fuels on environment parameters of diesel engines. Based on the recorded ecological-related parameters of the engine, such as concentration of hydrocarbons, nitrogen oxides and soot, corresponding charts were made (Figs. 7-9).

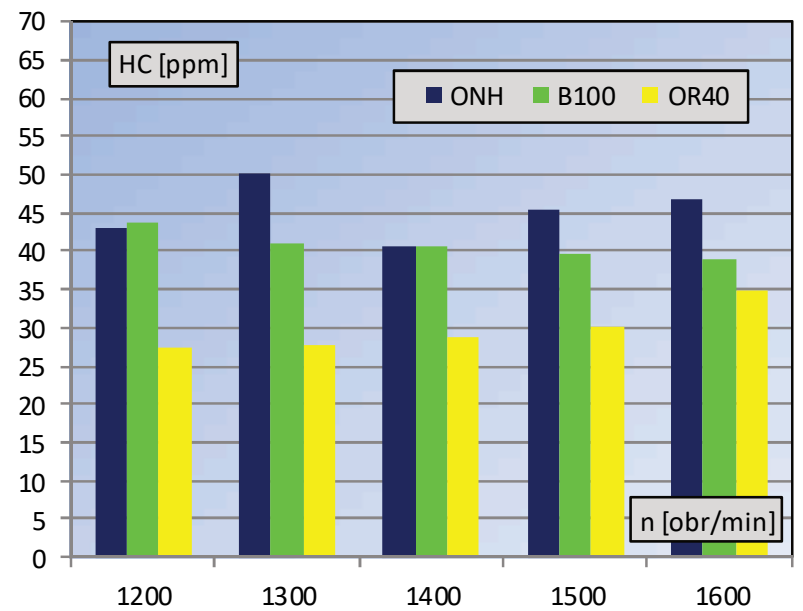

Fig. 7. Concentration of hydrocarbons $\mathrm{HC}$ in exhaust gases for test engine performance characteristics

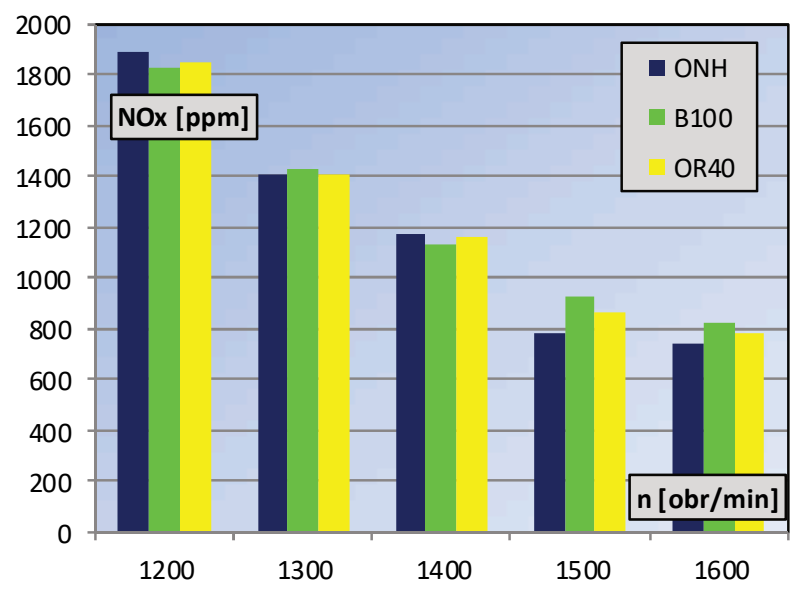

Fig. 8. Concentration of nitrogen oxides $\mathrm{NO}_{\mathrm{x}}$ in exhaust gases for test engine performance characteristics

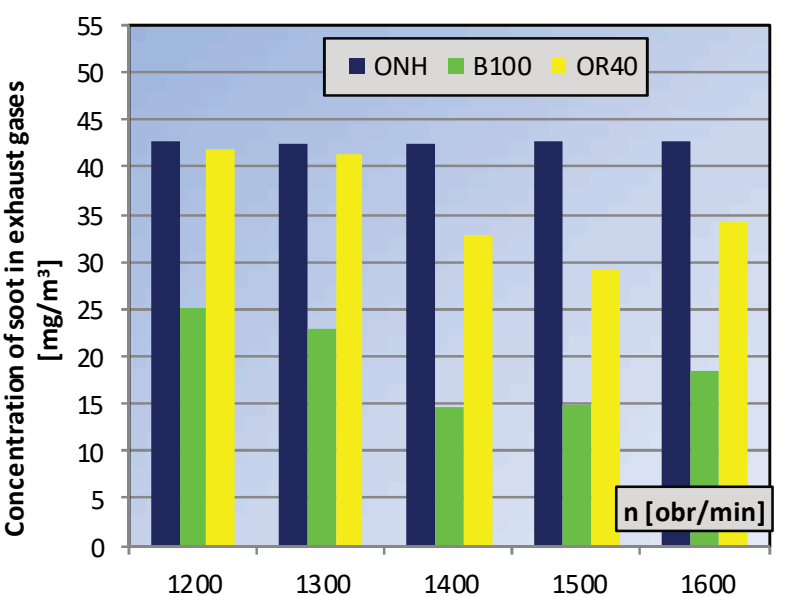

Fig. 9. Concentration of soot in exhaust gases for test engine performance characteristics

Figs 7-9 presents results of test with three fuel types (ONH, B100, OR40) in which concentrations of hydrocarbons, nitrogen oxides, and soot in exhaust gases were determined. Analysis of the results revealed that concentration of nitrogen oxides in the exhaust gases increases with decreasing engine speed. This follows from the fact that the decrease of the engine speed was accompanied by an increase of the load which in turn resulted in an increase of the exhaust gases temperature and the related increase of nitrogen oxides emissions.

For given engine speed, the injection duration was selected so that the force applied to the brake reached its maximum at the assumed smoke opacity of exhaust gas on the level of 25 HRT corresponding to concentration of soot in the exhaust gases of about $42 \mathrm{mg} / \mathrm{m}^{3}$ (which can be clearly seen in Fig. 9). Determination of the parameter was performed for $\mathrm{ONH}$ diesel fuel which was selected a reference fuel. Under the adopted assumptions, concentration of soot in exhaust gases for the other two fuels was lower, though varied, depending on the engine speed.

\section{Summary and conclusions}

Properties of substitution fuels which can be potentially used in diesel engines, are usually compared to those of regular diesel fuel. Results of determination of physicochemical properties of fuels and experiments carried out on the engine test bench were used to assess the effect of individual fuel parameters on ecological-related parameters of the test engine.

An important parameter of fuels is their viscosity which significantly affects both the fuel spraying and combustion process and as a consequence, concentration of toxic components in exhaust gases.

The results presented in Figs 7-9 show that relatively small decrease of the derived cetane number results in reduction of hydrocarbons $\mathrm{HC}$ and soot content in exhaust gases; as far as concentration of nitrogen oxides $\mathrm{NO}_{\mathrm{x}}$ is concerned, increase of the autoignition delay result in a slight increase of the parameter (compared to the increase of the combustion delay time and reduction of the derived cetane number value which show more distinct effect on the increase of concentration of nitrogen oxides). 


\section{Bibliography}

[1] BACZEWSKI, K., KAŁDOŃSKI, T. Paliwa do silników o zapłonie samoczynnym. WKE, Warszawa 2008.

[2] BALAWENDER, K., KUSZEWSKI, H., LEJDA, K., LEW K. The study on injection parameters of selected alternative fuels used in diesel engines. IOP Conf. Series: Materials Science and Engineering. 2016, 148, 012070.

[3] JAWORSKI, A., KUSZEWSKI, H., LEW, K., USTRZYCKI, A. Ocena przydatności paliw zastępczych do silników o ZS autobusów miejskich na podstawie wybranych parametrów wtrysku. Systemy i Środki Transportu Samochodowego. Monografia pod redakcją naukową Kazimierza Lejdy, Transport'12, 2012, 3, 143-148, Rzeszów.

[4] JAWORSKI, A., KUSZEWSKI, H., USTRZYCKI, A. Wpływ biododatków na parametry energetyczne paliw stosowanych w spalinowych napędach środków transportu. Międzynarodowa Konferencja Naukowa w Kijowie. ВІСНИК. 2011, 23, 95-100, Kijów.

\begin{abstract}
Krzysztof Balawender, DEng. - Faculty of Mechanical Engineering and Aeronautics at Rzeszów University of Technology.
\end{abstract}

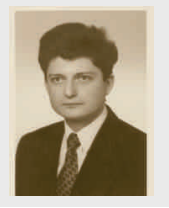

Hubert Kuszewski, DEng. - Faculty of Mechanical Engineering and Aeronautics at Rzeszów University of Technology.

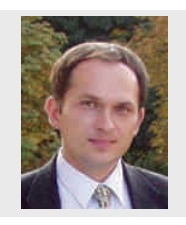

Krzysztof Lew, DEng. - Faculty of Mechanical Engineering and Aeronautics at Rzeszów University of Technology.

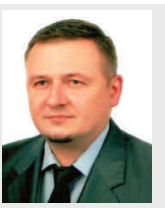

[5] LEJDA, K. Selected problems of fuel supply in highspeed diesel engines. Published by Meta. Lvov, 2004, 225.

[6] LEJDA, K., KUSZEWSKI, H., LEW, K. Wpływ właściwości fizykochemicznych paliw na parametry operacyjne silnika o ZS. Combustion Engines. 2015, 162(3), 915-920.

[7] LEW, K. Opracowanie kryteriów doboru paliw do specyfiki napędów wykorzystywanych w komunikacji miejskiej. Rozprawa doktorska. Poznań 2014.

[8] ORZECHOWSKI, Z., PRYWER, J. Rozpylanie cieczy w urządzeniach energetycznych. Wydawnictwa Naukowo-Techniczne. Warszawa 1994.

[9] UZDOWSKI, M. Problematyka wykorzystania paliw alternatywnych do zasilania silników trakcyjnych. MOTROL. 2008, 143-146.

[10] WIŚLICKI, B. Eksploatacja silników Diesla w aspektach ochrony środowiska w Polsce. Paliwa, Oleje $i$ Smary w Eksploatacji. 2000, 73, 34-38.

[11] Worldwide Fuel Charter, September 2006.

[12] ZABŁOCKI, M. Wtrysk i spalanie paliwa w silnikach wysokoprężnych. Wydawnictwo Komunikacji $i$ Łaczności. Warszawa 1976.

\footnotetext{
Dariusz Konieczny, MEng. - Faculty of Mechanical Engineering and Aeronautics at Rzeszów University of Technology.
}

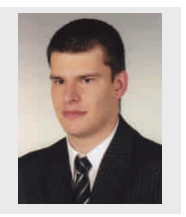

Prof. Kazimierz Lejda, DSc., DEng. - Faculty of Mechanical Engineering and Aeronautics at Rzeszów University of Technology.

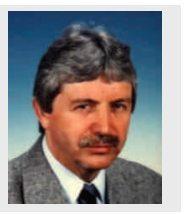

Paweł Wojewoda, DEng. - Faculty of Mechanical Engineering and Aeronautics at Rzeszów University of Technology.

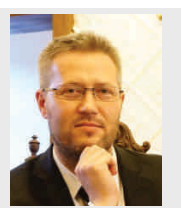

